\title{
DNA barcoding of lamp shells (Brachiopoda: Lingula anatina) from Probolinggo, East Java, Indonesia
}

\author{
RENI AMBARWATI ${ }^{1, \boldsymbol{v}}$, DWI A. RAHAYU ${ }^{1}$, FIDA RACHMADIARTI ${ }^{2}$, FIRAS KHALEYLA ${ }^{3}$ \\ ${ }^{1}$ Laboratory of Animal Systematics, Department of Biology, Faculty of Mathematics and Natural Sciences, Universitas Negeri Surabaya. Jl. Ketintang, \\ Gayungan, Surabaya 60231, East Java, Indonesia. Tel./fax.: +62-31-8296427, `email: reniambarwati@unesa.ac.id \\ ${ }^{2}$ Laboratory of Ecology, Department of Biology, Faculty of Mathematics and Natural Sciences, Universitas Negeri Surabaya. Jl. Ketintang, Gayungan, \\ Surabaya 60231, East Java, Indonesia \\ ${ }^{3}$ Laboratory of Animal Structure, Department of Biology, Faculty of Mathematics and Natural Sciences, Universitas Negeri Surabaya. Jl. Ketintang, \\ Gayungan, Surabaya 60231, East Java, Indonesia
}

Manuscript received: 25 November 2020. Revision accepted: 14 March 2021.

\begin{abstract}
Ambarwati R, Rahayu DA, Rachmadiarti F, Khaleyla F. 2021. DNA barcoding of lamp shells (Brachiopoda: Lingula anatina) from Probolinggo, East Java, Indonesia. Biodiversitas 22: 1764-1774. Lingula anatina is one of brachiopods found in tropical regions, however, the reports on this species from South East Asia is currently limited. This study, therefore, aims to identify the Cytochrome Oxidase subunit I (COI) sequence and phylogenetic of lamp shells from Probolinggo, Indonesia. A total of five samples of lamp shells were collected from Probolinggo, Indonesia, then identified based on morphological characters, and the identification was confirmed using molecular data. Subsequently, molecular characterization and identification were conducted based on 657 bp of COI gene similarity, sequence variation, genetic distance, phylogenetic topology, and BOLD System. According to the results, the Lingula species found in Probolinggo Indonesia was Lingula anatina. The median-joining network and Automatic Barcode Gap Discovery (ABGD) analysis showed this Lingula anatina population from Probolinggo had relatives of 22 haplotypes and divided into six haplogroups. Furthermore, the population belonged to the same haplogroup but had different haplotypes. Thus, this study provides more information for Lingula anatina phylogenetic and haplotype studies.
\end{abstract}

Keywords: Brachiopod, DNA barcode, haplotype, Lingula anatina, species identification

\section{INTRODUCTION}

The phylum Brachiopoda is a minor phylum, widely known as "living fossils", and several studies reported the existence of this phylum from middle to Upper Jurassic (Alberti et al. 2017) as well as Middle Triassic periods (Feldman 2017). Currently, living brachiopods are comprised of 116 genera and 391 species (Emig et al. 2013), and the distribution of this phylum has been reported previously in several locations, including, Queensland, Australia (Kenchington and Hammond 1978), North Western Philippines (Leopardas et al. 2016), South China Sea (Bitner and Romanin 2018), Japan (Goto et al. 2014) and India (Mitra and Pattanayak 2013; Samanta et al. 2014; Samanta et al. 2015; Nayak et al. 2018).

Brachiopods are also present in Indonesian coastal waters. The Siboga Expedition (1899-1900) found and reported 13 brachiopod species from Indonesia, identified as genus Lingula, Discinisca, Tugulorbynchia, Basiliola, Terebratulina, Gryphus, Campages, Jolonica, and Frenulina (Jackson and Stiasny, 1937). Meanwhile, Sahidin et al. (2018) reported the presence of brachiopods in Banten, Indonesia, and Darmarini et al. (2017) disclosed new findings of Lingula sp. from Damar Lubuk (Aceh). Rakmawati and Ambarwati (2020) also recorded the occurrence of lamp shells in Madura Strait, East Java Indonesia. However, the species identification of this population has not currently been confirmed.
Most studies on brachiopods in Indonesia were conducted based on morphological data. Ambarwati et al. (2019) examined brachiopods, actively collected by local people in Probolinggo and identified the population morphologically as Lingula cf. anatina. However, this finding needs to be confirmed using molecular identification, due to insufficient data on this taxon in the region.

The DNA barcode of Cytochrome Oxidase subunit I (COI) gene is one of the frequently used mitochondrial DNA markers for identifying taxonomic units. COI gene is used to identify and analyze phylogenetic relationships, even down to species level (Hebert et al. 2003). Furthermore, DNA barcoding is connected comprehensively to morphological analysis (Hebert et al. 2004); (Hebert and Gregory 2005); Hajibabaei et al. 2007; Waugh et al. 2008), and is, therefore, suitable for classifying and verifying species identification, for instance, Lingula sp. of brachiopod. The COI gene has the potential to identify genetic relationships at the species level and is a suitable standardized barcode region (Anzani et al. 2019; Hajibabaei et al. 2007; Wibowo et al. 2013; Jefri et al. 2015).

A study by Endo et al. (2005) on Lingula anatina based on COI gene stated the brachiopod's characteristic mitochondrial genome structure exhibits a number of unusual features, including large genome size, elongated genes, divergent gene sequences, and unique gene. In 
addition, the geographic population structure in Lingula from Japan and Hongkong based on a short 200 bp segment of the COI gene, had also been previously studied, and distinct differentiation was discovered among the population (Endo et al. 2005).

This study presents the first molecular scientific study to confirm molecular identification of Indonesian brachiopod (Lingula anatina) found in Probolinggo, East Java, based on DNA Barcode COI. The genetic information of brachiopod at the molecular level is hoped to provide information for future genetic population studies and conservation efforts, thus, maintaining the local species' sustainability. Meanwhile, the information on genetic diversity is useful for increasing the number of populations as well as preventing inbreeding, and consequently promoting genetic diversity.

\section{MATERIALS AND METHODS}

\section{Sampling}

For this study, samples were collected from Bee Jay Bakau Resort (BJBR) Probolinggo, East Java, Indonesia (743'42.15" S $113^{\circ} 13$ '24.93' E), and preserved in absolute ethanol, prior to morphological and molecular identification. Subsequently, morphological identification was conducted based on the shells and pedicle characteristic features, and with reference to previous studies (Mitra and Pattanayak 2013; Samanta et al. 2014; Samanta et al. 2015).

\section{DNA isolation}

The isolation of brachiopod DNA was performed using DNeasy Blood and Tissue Kits (QIAGEN), with several modifications, and all DNA extraction products were stored at $-20^{\circ} \mathrm{C}$. Subsequently, a quantitative test was immediately carried out using the NANO DROP 2000 UV spectrophotometer, and about $3 \mu$ of Isolated DNA from each sample was mixed with $1 \mu \mathrm{l}$ of loading dye and $2 \mu \mathrm{l}$ of sterile distilled water. The mixture of sample DNA, sterile distilled water, and loading dye were then carefully placed into an agarose gel with a micropipette. This was followed by conducting electrophoresis, using a voltage source of $100 \mathrm{~V}, 200 \mathrm{MA}$ for 1 hour, and the separated DNA was then used as template to amplify a $657 \mathrm{bp}$ fragment of the COI gene using the primers LCO1490 5' -GGT-CAAATC-ATA-AAG-ATA-TTG-G-3' (forward) and HCO2198 5'-TAA-ACT-TCA-GGG-TGA-CCA-AAA-AAT-CA-30 (reverse) to obtain a 658 bp sequence (Folmer et al. 1994). Meanwhile, quantitative test on total DNA was conducted using UV spectrophotometer NANO DROP 2000.

\section{PCR cycle, and sequencing}

PCR reaction was carried out in a thermal cycler under the conditions of $1 \mathrm{~min}$ of initial denaturation at $94^{\circ} \mathrm{C}, 40$ cycles of $45 \mathrm{~s}$ of denaturation at $94^{\circ} \mathrm{C}$, annealing at $45^{\circ} \mathrm{C}$ for $45 \mathrm{~s}$, and extension at $72^{\circ} \mathrm{C}$ for $1 \mathrm{~min} 30 \mathrm{~s}$, and a final extension at $72^{\circ} \mathrm{C}$ for $10 \mathrm{~min}$, PCR composition of for COI gene with total solution of $50 \mu \mathrm{L}$ (according to the procedure of iNtRON Biotechnology) consisted of 2x PCR Master Mix Solution $25 \mu \mathrm{L}$, DNA template 1-2 $\mu \mathrm{L}$, Primer
F $(10 \mathrm{pmol} / \mu \mathrm{L}) 1 \mu \mathrm{L}$, Primer R $(10 \mathrm{pmol} / \mu \mathrm{L}) 1 \mu \mathrm{L}$, and double-distilled water (ddH2O) 21-22 $\mu \mathrm{L}$. The PCR products were visualized in $1 \%$ agarose gels stained with ethidium bromide. Subsequently, the purified DNA products (Forward and Reverse) were sent to First Base Malaysia for sequencing. Furthermore, the DNA sequence analyzer used was 373XL DNA analyzer with BigDye v3.1, and each DNA specimen was sequenced for the COI barcode region's $657 \mathrm{bp}$.

\section{Genetic analysis}

Analysis of the COI gene sequence was conducted using several software, including DNA Baser (Automatic DNA Sequence Assembly) and DNA Star (DNASTAR Inc., Madison, WI, U.S.A.) to create consensus sequences, BLAST to determine the compatibility of the target gene with the Query obtained from GenBank, Clustal-X (Chenna et al. 2003) to draw multiple alignments between the COI gene for samples and the database of closely related of Lingula sp. collected from BJBR, Probolinggo, East Java. Meanwhile, phylogenetic analysis was also conducted based on the samples and genetic data of related taxon retrieved from GenBank (Table 1). Subsequently, the final alignment consisting of 657 base pairs was then verified into the Barcode of Life Data System (BoLD System) (www.barcodinglife.org) to verify the samples' identity and test for homology with the available sequences in GenBank.

The alignment results were identified online at the Bold System (www.barcodinglife.org) and checked for homology, using the GenBank by comparison with compared with related species. In addition, records from different subphyla species Novocrania japonicas and Pictothyris picta, were retrieved and used as outgroups (Kim et al. 2017). The last step was the construction of phylogenetic topology using MEGA X (Tamura et al. 2013) computer program with Neighbour Joining method, using Kimura 2 Parameter model on random tree algorithm, as well as Maximum Likelihood method using HKY (Hasegawa Kishino Yano) algorithmic calculation model (Tamura et al. 2013). Meanwhile, tree evaluation was conducted using a bootstrap analysis of 1000 repetitions, and calculation of similarity values used the formula:

\section{Similarity percentage $=(1-$ Genetic Distance $) \times 100 \%$}

The substitution of nucleotide base transitions and transversion was calculated using the Kimura 2 model, while further analysis of Lingula sp. with related species was analyzed for common haplotype sequences, using DNASP. V.5.0 computer program (Rozas and Rozas, 1995). Furthermore, construction of the haplogroup for Lingula sp. with related species from GenBank were analyzed using median-joining method as well as the Network 4.1.0.8 computer program (Martins et al. 2013). Also, the barcode gap analysis of Lingula sp. species generated by Automatic Barcode Gap Discovery was used to strengthen the identification of this species and grouping analysis (Puillandre et al. 2012). 
Table 1. Sample code of Lingula in this study and retrieved data from GenBank

\begin{tabular}{|c|c|c|c|}
\hline Species & Location & Country & Acc. number GenBank \\
\hline Lingula anatina & Amami & Japan & KP881498.1 \\
\hline Lingula anatina & N/A & Hongkong & $\mathrm{AB} 056461.1$ \\
\hline Lingula anatina & Qinhuangdao & China & GU056040 \\
\hline Lingula anatina & Qinhuangdao & China & GU056041 \\
\hline Lingula anatina & N/A & Japan & AB026520.1 \\
\hline Lingula anatina & N/A & Japan & $\mathrm{AB} 056460.1$ \\
\hline Lingula anatina & - & South Korea & KY091122.1 \\
\hline Lingula anatina & - & South Korea & KY091123.1 \\
\hline Lingula anatina & - & South Korea & KY091124.1 \\
\hline Lingula anatina & - & South Korea & KY091125.1 \\
\hline Lingula shantungensis & N/A & Japan & AB056459 \\
\hline Lingula adamsi & Muan & South Korea & $\mathrm{AB} 128063.1$ \\
\hline Lingula adamsi & Muan & South Korea & AB128062.1 \\
\hline Lingula adamsi & Muan & South Korea & $\mathrm{AB} 128061.1$ \\
\hline Lingula adamsi & Muan & South Korea & $\mathrm{AB} 128060.1$ \\
\hline Lingula adamsi & Muan & South Korea & $\mathrm{AB} 128059.1$ \\
\hline Lingula adamsi & Muan & South Korea & AB128057.1 \\
\hline Lingula adamsi & Muan & South Korea & $\mathrm{AB} 128056.1$ \\
\hline Lingula adamsi & Muan & South Korea & AB128055.1 \\
\hline Lingula sp. 1 & BJBR Probolinggo & East Java & MW454810.1 \\
\hline Lingula sp. 2 & BJBR Probolinggo & East Java & MW454813.1 \\
\hline Lingula sp. 3 & BJBR Probolinggo & East Java & MW454814.1 \\
\hline Lingula sp. 4 & BJBR Probolinggo & East Java & MW454800.1 \\
\hline Lingula sp. 5 & BJBR Probolinggo & East Java & MW454815.1 \\
\hline Pictothyris picta & N/A & Japan & AB026506 \\
\hline Novocrania japonicus & N/A & Japan & AB026519 \\
\hline
\end{tabular}

\section{RESULTS AND DISCUSSION}

The morphological characters of Lingula were identified as outlined below. Shells, length: $39.38 \pm 4.41$ mm; width: $18.27 \pm 2.75 \mathrm{~mm}$; thickness: $8.18 \pm 0.97 \mathrm{~mm}$; shape elongated; lateral margins subparallel; anterior margin slightly convex; smooth external valve surface; distinct growth lines; greenish (varies from translucent green to dark green) color in several specimens. Pedicles, length: $4.45 \pm 0.97 \mathrm{~cm}$; whitish color; length of pedicles attached in substrate: $1.41 \pm 0.56 \mathrm{~cm}$ (Figure 1).

These morphological features indicated the species of Lingula found in this study was Lingula anatina Lamarck 1801 (Mitra and Pattanayak 2013; Samanta et al. 2014 Samanta et al. 2015). This finding is supported by previous report published by Ambarwati et al. (2019). Subsequently, the results of morphological identification were further confirmed using molecular methods.

A 657-bp segment of the mitochondrial COI gene was sequenced for five individuals of Lingula sp. from Probolinggo, East Java, with ten sequences Lingula anatina, Lingula shantungensis, Lingula adamsi, as well as two outgroup species (extracted from GenBank). The five samples all had good quantity (100-200 ng /ul) and quality (pure DNA with no contamination) (Figure 2).

A total of 657 nucleotide bases were successfully translated into protein without stop codon in the middle of the sequence (pseudogene) among the 5 sequenced samples, using Expasy online (Artimo et al. 2012).
Furthermore, a total of 219 amino acids were successfully translated without insertions and deletions. Subsequently, the nucleotide bases were further analyzed by online identification, through the BOLD System (Table 2). The similarities of the Lingula sp. 1; Lingula sp. 2; Lingula sp. 3; Lingula sp. 4 and Lingula sp. 5 to Bold data of Lingula anatina were categorized as very high, at 91.2-92.28\%, and the high similarity between Lingula sp. from BJBR Probolinggo as well as Lingula anatina, is due to the COI Barcode sequence's high homology with the Bold system database.

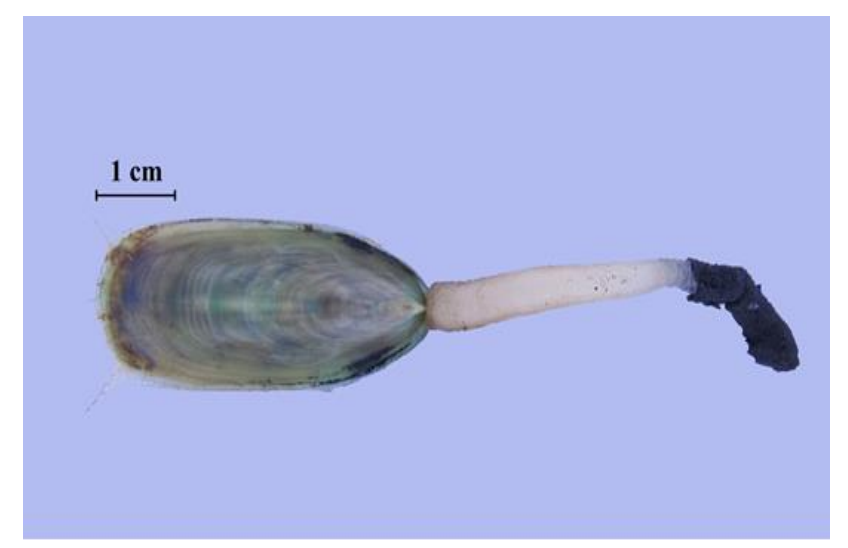

Figure 1. Preserved specimen of Lingula anatina from Probolinggo, Indonesia 
Table 2. The three highest compatibility values from identification through the BOLD System with a representation of the similarity value

\begin{tabular}{|c|c|c|c|c|c|c|c|c|}
\hline Sample & Phylum & Class & Order & Family & Genus & $\begin{array}{c}\text { Species } \\
\text { (3 highest) }\end{array}$ & Similarity & Status \\
\hline \multirow{3}{*}{ Lingula sp.1 } & Brachiopoda & Lingulata & Lingulida & Lingulidae & Lingula & anatina & 92.28 & Published \\
\hline & & & & & & anatina & 76.29 & Private \\
\hline & & & & & & anatina & 76.25 & Private \\
\hline \multirow[t]{3}{*}{ Lingula sp. 2} & Brachiopoda & Lingulata & Lingulida & Lingulidae & Lingula & anatina & 91.2 & Published \\
\hline & & & & & & anatina & 76.08 & Published \\
\hline & & & & & & anatina & 75.94 & Private \\
\hline \multirow[t]{3}{*}{ Lingula sp.3 } & Brachiopoda & Lingulata & Lingulida & Lingulidae & Lingula & anatina & 92.28 & Published \\
\hline & & & & & & anatina & 76.29 & Published \\
\hline & & & & & & anatina & 76.25 & Private \\
\hline \multirow[t]{3}{*}{ Lingula sp.4 } & Brachiopoda & Lingulata & Lingulida & Lingulidae & Lingula & anatina & 92.28 & Published \\
\hline & & & & & & anatina & 76.29 & Published \\
\hline & & & & & & anatina & 76.25 & Private \\
\hline \multirow[t]{3}{*}{ Lingula sp.5 } & Brachiopoda & Lingulata & Lingulida & Lingulidae & Lingula & anatina & 91.24 & Published \\
\hline & & & & & & anatina & 76.08 & Published \\
\hline & & & & & & anatina & 75.94 & Private \\
\hline
\end{tabular}

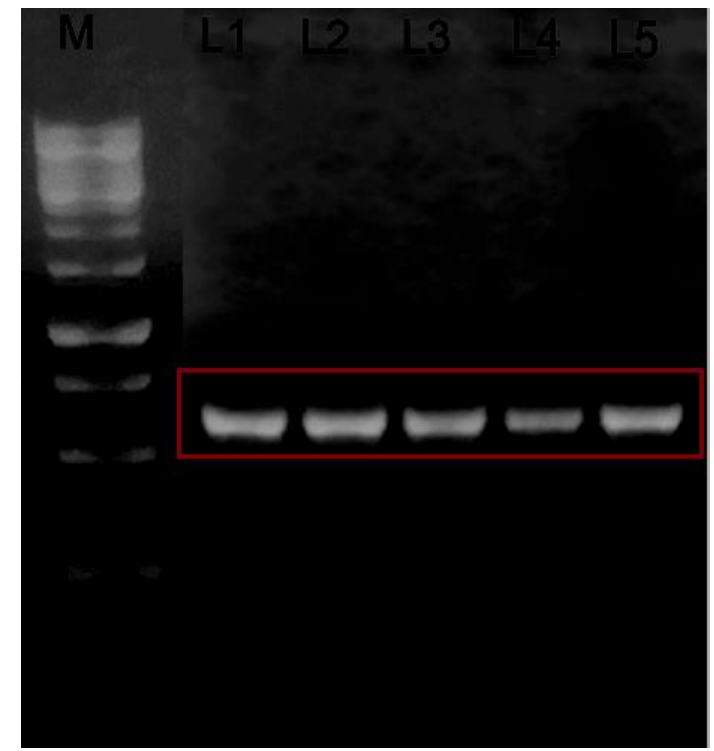

Figure 2. Electrophoregram of the amplification result of the COI gene specimen Lingula sp. in 1\% agarose gel (Note: M: DNA Ladder 1 kb; L1: Lingula sp. 1; L2: Lingula sp. 2; L3: Lingula sp. 3; L4: Lingula sp. 4 and L5: Lingula sp. 5)

\section{Variation of nucleotide bases}

According to (Buhay 2009) one of the possible cases arising in species identification using $\mathrm{COI}$ is the concern of amplification of COI-like sequence or pseudogene originating from mitochondria (numt). In this study, consensus sequence analysis was performed with protein translation as COI is a coding region to confirm whether this sequence actually originated from the COI gene mitochondrial DNA or not. The results of the alignment analysis for Lingula sp. found at BJBR Probolinggo Beach in this study showed no insertions and deletions. In addition, the heterozygosity of chromatogram peaks was carefully examined to confirm the presence of numt (Bensasson et al. 2001).

The COI gene barcode sequence showed GC nucleotide base composition was lower compared to AT. Table 3 shows the composition of the GC nucleotide base ranges from $60.33 \%-60.88 \%$. This is similar to the previous findings, where the number of AT nucleotide bases in Nomei fish from North Kalimantan waters was higher, compared to GC base pair number (Nugroho et al. 2017). These variations are probably related to metabolic physiology of the organism (Priyono et al. 2018).

COI gene transition type nucleotide base variations were found to be more common, compared to transversion. Based on all Lingula sp. Samples and relatives, 26 nucleotide base substitutions were found (Table 4). The alignment results showed 7 unique nucleotide bases (automorphic) were found in Lingula sp. from BJBR Probolinggo compared to related species. Unique nucleotide base characters were found in nucleotide bases number $21,54,108,159,183,254$, and 482. For instance, in nucleotide bases number 54, Lingula sp. had nucleotide base Adenine (A), while Lingula adamsi group had Thymine (T) and Lingula anatina had Cytosine (C) and Thymine (T). Thus, pure COI genes were successfully obtained without pseudogene in the amino acid sequences, meaning, COI gene sequences are potentially useful as standard barcode identification for Lingula $\mathrm{sp}$. in Indonesian waters. The presence of diagnostic nucleotide bases was the main requirement in species identification using DNA Barcoding, as well as the presence of simple diagnostic nucleotide (sND) characters (Wong et al. 2009) In addition, COI gene showed high genetic variation within species (Susanto et al. 2012).

\section{Genetic distance}

The genetic distance (Table 4) between the samples and close relatives was calculated using the 2-parameter kimura model. According to the results, the average genetic distance between Lingula sp. was $0.02 \%$, compared to Lingula anatina (Amami-Japan), with $0.08 \%$. This indicated the intraspecies' genetic diversity was very low or below 2\%. A genetic distance value of above $2 \%$ indicates species different from other group members, while a value below $3 \%$ indicates the group or cluster belongs to the same species (Wong et al. 2009). 
Table 3. The composition of the COI Lingula sp. from Probolinggo, Indonesia

\begin{tabular}{|c|c|c|c|c|}
\hline \multirow{2}{*}{ Specimens } & \multirow{2}{*}{ Conserved sites (bp) } & \multicolumn{2}{|c|}{ Composition of nucleotide bases (\%) } & \multirow{2}{*}{ Amount of amino acid translation } \\
\hline & & AT & GC & \\
\hline Lingula sp. 1 & 657 & 60.88 & 39.12 & 219 \\
\hline Lingula sp. 2 & 657 & 60.33 & 39.67 & 219 \\
\hline Lingula sp. 3 & 657 & 60.88 & 39.12 & 219 \\
\hline Lingula sp. 4 & 657 & 60.88 & 39.12 & 219 \\
\hline Lingula sp. 5 & 657 & 60.33 & 39,67 & 219 \\
\hline
\end{tabular}

Interesting results were shown in Lingula sp. identified based on the value of the intraspecies genetic distance. These findings were supported by Mikkelsen et al. (2007) stating for marine mollusks, the pairwise intraspecific genetic distances range from 0-1.9 percent, while pairwise interspecific genetic distances range from 14-77 percent. The genetic distance between other Lingula anatina (Japan, South Korea) was $0.34 \%$, distance of Lingula sp. to Lingula adamsi was 0.48 . This genetic distance exceeded the threshold limit of the standardization (Hajibabaei et al. 2007), meaning the species was a different species, with high variation of nucleotide bases. This implies Lingula sp. BJBR and Lingula adamsi had high genetic diversity, and the high genetic distance (Kimura 2 parameter model) between a population or individual indicated isolation from the other (geographic isolation). The genetic distance indicated possible effect of geographical isolation on a population (Mikkelsen et al. 2007). A study by Yang et al.(2013) stated rapidly emerging evidence of genetic distances without readily observable phenotypic change (morphological stasis) during the evolutionary history of a lineage does not necessarily imply genetic stasis.

The genetic diversity of Lingula might also be affected by environmental factors, including temperature, salinity, and irradiation stress, with significant contributions to mitochondrial sequence variation and mutation rate of this marker (Wallace and Chalkia 2013), and Lingua anatina sequences showed genetic diversity to the locality under these environmental factors (Luo et al. 2015). Conversely, the genetic distance between Korean and Chinese population of Lingula was high, due to correlation between geographical and genetic distances (Kim et al. 2017). Based on the current findings, there was an accepted correlation between the two distances for Lingula sp. from BJBR, East Java as well as related species from GenBank. However, further study requires an adequate number of samples to determine the hypotheses of the relationship to this geographical distance.

\section{Genetic relationships}

The phylogenetic tree topology construction between the sample and close relative (GenBank) was analyzed using NJ and ML methods, with the K2P calculation model (bootstrap 1000 times) (Figure 3). Based on the cladogram, this was then divided into two large clusters, Lingula anatina and Lingula adamsi clades. Lingula sp. from BJBR was found to belong to a separate clade with close relative Lingula anatina (Amami-Japan). The first cluster divided Lingula sp. BJBR East Java with Lingula anatina (Amami-
Japan) at bootstrap value of 100/99. According to the bootstrap value of each OTU ranging from 96 to 100, the grouping had a high degree of similarity. Thus, the NJ and ML methods showed a constant relationship between Lingula sp. BJBR and relatives, only differed in the bootstrap value (Madduppa et al. 2017). Also, the percentage of bootstrapping 1000 times repetitions with a value above $80 \%$ in the fork showed very good results, strongly confirms the sample examined was in a species (Hesterberg 2015).

In this study, haplotype was analyzed using five Lingula sp. individuals. The median-joining network described the variation of Lingula sp. with related species into 22 haplotypes and six haplogroups, based on DNAsp5. Figure 5 shows the Lingula sp. sample was found to belong to the same haplogroup but different haplotype (haplotype 2 (Lingula sp. 1, 3 and 4), haplotype 3 (Lingula sp. 2), and haplotype 4 (Lingula sp. 5)). Different haplotypes from the same location indicate that the individuals have heteroplasmic MtDNA. This is a stem cell with mutant mitochondria and wild-type genetic material, causing the daughter cells to have mutant and normal genetic material, if replicative segregation occurs (Esa et al. 2008). In the case of Lingula sp., the mitochondrial DNA collected was probably heteroplasmic, resulting in different haplotypes. Haplotype Lingula sp. From Probolinggo, East Java was different, because the five individuals were not homologous to reference species, despite being in the same haplogroup as Japanese Lingula anatina Amami. This grouping was based on nucleotide base substitution, due to geographical isolation.

Further analysis to strengthen relation of Lingula sp. to close relatives was carried out using ABGD web (Puillandre et al. 2012). This segregates species according to the maximum intraspecific distance range (Figure 6A). Figure 6C shows OTU Lingula sp.'s initial partition, compared at relative constant of 6 . This was in accordance with the results of grouping Haplotype networking, dividing the species into 6 haplogroups with 22 haplotypes. Haplogroup 1 consisted of Group [1] n: 6; id: KP881498.1. Lingula_anatina (Amami-Japan) Lingula_sp._4_ (BJBREast_Java) Lingula_sp._3_(BJBR-East_Java) Lingula_sp._5_ (BJBR-East_Java) Lingula_sp._2_ (BJBR-East_Java) Lingula_sp._1_(BJBR-East_Java). In addition, the ABGD analysis revealed a larger number of lineages due to the division of Lingula anatina from Probolinggo, as well as reference species. This strengthened three lineages, despite the relatively small genetic distances, $(0.02 \%$ and $0.48 \%$, respectively), compared to OTU from reference species. 
Table 4. Variations of nucleotide bases Lingula sp. compared to close relatives based on the COI gene and characteristic nucleotide (automophi)

\begin{tabular}{|c|c|c|c|c|c|c|c|c|c|c|c|c|c|c|c|c|c|c|c|c|c|c|c|c|c|c|}
\hline \multirow{2}{*}{ Specimen } & \multicolumn{26}{|c|}{ Variable sites } \\
\hline & 2 & 12 & 21 & 36 & 39 & 42 & 54 & 58 & 85 & 108 & 115 & 140 & 159 & 183 & 214 & 254 & 252 & 277 & 290 & 362 & 366 & 386 & 419 & 470 & 479 & 482 \\
\hline KP881498.1. Lingula anatina (Amami-Japan) & $\mathrm{G}$ & G & A & $\mathrm{T}$ & A & $\mathrm{T}$ & $\mathrm{T}$ & $\mathrm{C}$ & $\mathrm{C}$ & $\mathrm{T}$ & $\mathrm{C}$ & $\mathrm{A}$ & $\mathrm{T}$ & $\mathrm{C}$ & $\mathrm{C}$ & A & $\mathrm{C}$ & $\mathrm{C}$ & A & $\mathrm{C}$ & $\mathrm{C}$ & $\mathrm{C}$ & G & $\mathrm{T}$ & $\mathrm{T}$ & $\mathrm{T}$ \\
\hline MW454800.1 Lingula sp. 4 (BJBR-East Java) & - & - & G & - & - & - & A & - & - & A & - & - & A & $\mathrm{T}$ & - & G & • & - & - & • & - & - & - & - & - & A \\
\hline MW454814.1 Lingula sp 3 (BJBR East Java) & - & - & G & • & - & • & A & - & - & A & - & • & A & $\mathrm{T}$ & - & G & • & - & - & - & - & - & - & - & - & A \\
\hline MW454815.1 Lingula sp. 5 (BJBR-East_Java) & - & - & $\mathrm{G}$ & - & - & - & A & - & - & A & - & - & A & $\mathrm{T}$ & - & G & - & • & - & • & • & - & - & - & - & A \\
\hline MW454813.1 Lingula sp. 2 (BJBR-East_Java) & - & - & G & - & - & - & A & - & - & A & - & - & A & $\mathrm{T}$ & - & G & - & - & • & - & • & • & - & - & - & A \\
\hline MW454810.1 Lingula sp. 1 (BJBR-East_Java) & - & - & G & - & - & - & A & - & - & A & - & - & A & $\mathrm{T}$ & - & G & - & - & • & - & - & • & - & - & - & A \\
\hline AB128055.1. Lingula adamsi (South Korea) & $\mathrm{C}$ & $\mathrm{C}$ & - & A & G & A & - & $\mathrm{T}$ & $\mathrm{T}$ & G & $\mathrm{T}$ & $\mathrm{C}$ & $\mathrm{C}$ & $\mathrm{T}$ & A & $\mathrm{T}$ & $\mathrm{T}$ & $\mathrm{T}$ & G & $\mathrm{T}$ & A & G & A & G & G & - \\
\hline AB056459.1. Lingula shantungensis (Japan) & $\mathrm{C}$ & $\mathrm{C}$ & - & A & G & A & - & $\mathrm{T}$ & $\mathrm{T}$ & G & $\mathrm{T}$ & $\mathrm{C}$ & $\mathrm{C}$ & $\mathrm{T}$ & A & $\mathrm{T}$ & $\mathrm{T}$ & $\mathrm{T}$ & G & $\mathrm{T}$ & A & G & A & $\mathrm{G}$ & G & - \\
\hline AB128059.1. Lingula adamsi (South Korea) & $\mathrm{C}$ & $\mathrm{C}$ & - & A & G & A & - & $\mathrm{T}$ & $\mathrm{T}$ & G & $\mathrm{T}$ & $\mathrm{C}$ & $\mathrm{C}$ & $\mathrm{T}$ & A & $\mathrm{T}$ & $\mathrm{T}$ & $\mathrm{T}$ & G & $\mathrm{T}$ & A & G & A & G & G & - \\
\hline AB128057.1. Lingula adamsi (South Korea) & $\mathrm{C}$ & $\mathrm{C}$ & - & A & G & A & - & $\mathrm{T}$ & $\mathrm{T}$ & G & $\mathrm{T}$ & $\mathrm{C}$ & $\mathrm{C}$ & $\mathrm{T}$ & A & $\mathrm{T}$ & $\mathrm{T}$ & $\mathrm{T}$ & G & $\mathrm{T}$ & A & G & A & G & G & - \\
\hline AB128060.1. Lingula adamsi (South Korea) & $\mathrm{C}$ & $\mathrm{C}$ & - & A & G & A & - & $\mathrm{T}$ & $\mathrm{T}$ & G & $\mathrm{T}$ & $\mathrm{C}$ & $\mathrm{C}$ & $\mathrm{T}$ & A & $\mathrm{T}$ & $\mathrm{T}$ & $\mathrm{T}$ & G & $\mathrm{T}$ & A & G & A & G & $\mathrm{G}$ & • \\
\hline AB128061.1. Lingula adamsi (South Korea) & $\mathrm{C}$ & $\mathrm{C}$ & - & A & G & A & - & $\mathrm{T}$ & $\mathrm{T}$ & G & $\mathrm{T}$ & $\mathrm{C}$ & $\mathrm{C}$ & $\mathrm{T}$ & A & $\mathrm{T}$ & $\mathrm{T}$ & $\mathrm{T}$ & G & $\mathrm{T}$ & A & G & A & $\mathrm{G}$ & G & - \\
\hline AB128056.1. Lingula adamsi (South Korea) & $\mathrm{C}$ & $\mathrm{C}$ & - & A & G & A & - & $\mathrm{T}$ & $\mathrm{T}$ & G & $\mathrm{T}$ & $\mathrm{C}$ & $\mathrm{T}$ & $\mathrm{T}$ & A & $\mathrm{T}$ & $\mathrm{T}$ & $\mathrm{T}$ & G & $\mathrm{T}$ & A & G & A & $\mathrm{G}$ & G & - \\
\hline AB128062.1. Lingula adamsi (South Korea) & $\mathrm{C}$ & $\mathrm{C}$ & - & A & G & A & - & $\mathrm{T}$ & $\mathrm{T}$ & G & $\mathrm{T}$ & $\mathrm{C}$ & $\mathrm{T}$ & $\mathrm{T}$ & A & $\mathrm{T}$ & $\mathrm{T}$ & $\mathrm{T}$ & G & $\mathrm{T}$ & A & G & A & $\mathrm{G}$ & G & • \\
\hline AB128063.1. Lingula adamsi (South Korea) & $\mathrm{C}$ & $\mathrm{C}$ & - & A & G & A & - & $\mathrm{T}$ & $\mathrm{T}$ & G & A & $\mathrm{T}$ & $\mathrm{T}$ & $\mathrm{T}$ & A & $\mathrm{T}$ & $\mathrm{T}$ & $\mathrm{T}$ & G & $\mathrm{T}$ & A & G & A & $\mathrm{G}$ & G & - \\
\hline AB026506.1. Pictothyris picta (Japan) & $\mathrm{C}$ & $\mathrm{C}$ & - & A & G & G & - & $\mathrm{T}$ & G & G & A & $\mathrm{T}$ & $\mathrm{T}$ & A & A & $\mathrm{C}$ & $\mathrm{T}$ & $\mathrm{T}$ & G & $\mathrm{T}$ & A & G & A & G & G & $\mathrm{C}$ \\
\hline AB026519.1. Novocrania japonicus (Japan) & $\mathrm{C}$ & $\mathrm{C}$ & - & A & $\mathrm{G}$ & G & - & $\mathrm{T}$ & $\mathrm{G}$ & G & $\mathrm{T}$ & - & $\mathrm{T}$ & A & A & $\mathrm{C}$ & $\mathrm{T}$ & $\mathrm{T}$ & G & $\mathrm{T}$ & A & G & A & $\mathrm{G}$ & G & G \\
\hline AB056461.1. Lingula anatina (Hongkong) & $\mathrm{C}$ & $\mathrm{T}$ & G & A & G & - & $\mathrm{C}$ & - & A & - & $\mathrm{T}$ & $\mathrm{C}$ & $\mathrm{T}$ & A & A & $\mathrm{T}$ & • & $\mathrm{T}$ & G & $\mathrm{T}$ & A & $\mathrm{T}$ & $\mathrm{T}$ & G & G & - \\
\hline AB026520.1. Lingula anatina (Japan) & $\mathrm{C}$ & $\mathrm{T}$ & G & A & G & • & $\mathrm{C}$ & - & A & - & $\mathrm{T}$ & $\mathrm{C}$ & $\mathrm{T}$ & A & A & $\mathrm{T}$ & • & $\mathrm{T}$ & G & $\mathrm{T}$ & A & $\mathrm{T}$ & $\mathrm{T}$ & $\mathrm{G}$ & G & - \\
\hline AB056460.1. Lingula anatina (Japan) & $\mathrm{C}$ & $\mathrm{T}$ & G & A & G & - & $\mathrm{C}$ & - & A & - & $\mathrm{T}$ & $\mathrm{C}$ & $\mathrm{T}$ & A & A & $\mathrm{T}$ & • & $\mathrm{T}$ & G & $\mathrm{T}$ & A & $\mathrm{T}$ & $\mathrm{T}$ & $\mathrm{G}$ & G & - \\
\hline GU056041.1. Lingula anatina & $\mathrm{C}$ & $\mathrm{T}$ & G & A & G & - & $\mathrm{C}$ & - & A & - & $\mathrm{T}$ & $\mathrm{C}$ & $\mathrm{T}$ & A & A & $\mathrm{T}$ & - & $\mathrm{T}$ & G & $\mathrm{T}$ & A & $\mathrm{T}$ & $\mathrm{T}$ & G & G & - \\
\hline GU056040.1. Lingula anatina (China) & $\mathrm{C}$ & $\mathrm{T}$ & G & A & G & - & $\mathrm{C}$ & - & A & - & $\mathrm{T}$ & $\mathrm{C}$ & $\mathrm{T}$ & A & A & $\mathrm{T}$ & - & $\mathrm{T}$ & G & $\mathrm{T}$ & A & $\mathrm{T}$ & $\mathrm{T}$ & $\mathrm{G}$ & G & - \\
\hline KY091122.1. Lingula anatina (South Korea) & $\mathrm{C}$ & $\mathrm{T}$ & G & A & G & 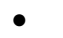 & & & A & & $\mathrm{T}$ & $\mathrm{C}$ & $\mathrm{T}$ & A & A & $\mathrm{T}$ & • & $\mathrm{T}$ & G & $\mathrm{T}$ & A & $\mathrm{T}$ & $\mathrm{T}$ & $\mathrm{G}$ & G & \\
\hline KY091123.1. Lingula anatina (South Korea) & $\mathrm{C}$ & $\mathrm{T}$ & G & A & G & 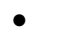 & 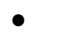 & 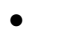 & A & 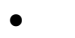 & $\mathrm{T}$ & $\mathrm{C}$ & $\mathrm{T}$ & A & A & $\mathrm{T}$ & • & $\mathrm{T}$ & G & $\mathrm{T}$ & A & $\mathrm{T}$ & $\mathrm{T}$ & G & G & - \\
\hline KY091124.1. Lingula anatina (South Korea) & & $\mathrm{T}$ & G & A & G & & & & A & & $\mathrm{T}$ & $\mathrm{C}$ & $\mathrm{T}$ & A & A & $\mathrm{T}$ & • & & G & $\mathrm{T}$ & A & $\mathrm{T}$ & $\mathrm{T}$ & G & G & \\
\hline KY091125.1. Lingula anatina (South Korea) & $\mathrm{C}$ & $\mathrm{T}$ & & & & & & & & & & $\mathrm{C}$ & $\mathrm{T}$ & & A & $\mathrm{T}$ & & & G & & & $\mathrm{T}$ & & & $\mathrm{G}$ & \\
\hline
\end{tabular}


Table 5. Genetic distance of Lingula sp. compared to related species

\begin{tabular}{|c|c|c|c|c|c|c|c|c|c|c|c|c|c|c|c|c|c|c|c|c|c|c|c|c|c|c|c|}
\hline No. & Specimen name & 1 & 2 & 3 & 4 & 5 & 6 & 7 & 8 & 9 & 10 & 11 & 12 & 13 & 14 & 15 & 16 & 17 & 18 & 19 & 20 & 21 & 22 & 23 & 24 & 25 & 26 \\
\hline 1 & KP881498.1. Lingula anatina (Amami-Japan) & & & & & & & & & & & & & & & & & & & & & & & & & & \\
\hline 2 & MW454800.1 Lingula sp. 4 (BJBR-East Java) & 0.000 & & & & & & & & & & & & & & & & & & & & & & & & & \\
\hline 3 & MW454814.1 Lingula sp 3 (BJBR East Java) & 0.000 & 0.000 & & & & & & & & & & & & & & & & & & & & & & & & \\
\hline 4 & MW454815.1 Lingula sp. 5 (BJBR-East_Java) & 0.024 & 0.024 & 0.024 & & & & & & & & & & & & & & & & & & & & & & & \\
\hline 5 & MW454813.1 Lingula sp. 2 (BJBR-East__Java) & 0.028 & 0.028 & 0.028 & 0.004 & & & & & & & & & & & & & & & & & & & & & & \\
\hline 6 & MW454810.1 Lingula sp. 1 (BJBR-East_Java) & 0.392 & 0.392 & 0.392 & 0.388 & 0.388 & & & & & & & & & & & & & & & & & & & & & \\
\hline 7 & AB128055.1. Lingula adamsi (South Korea) & 0.400 & 0.400 & 0.400 & 0.396 & 0.396 & 0.004 & & & & & & & & & & & & & & & & & & & & \\
\hline 8 & AB056459.1. Lingula shantungensis (Japan) & 0.400 & 0.400 & 0.400 & 0.396 & 0.396 & 0.004 & 0.004 & & & & & & & & & & & & & & & & & & & \\
\hline 9 & AB128059.1. Lingula adamsi (South Korea) & 0.400 & 0.400 & 0.400 & 0.396 & 0.396 & 0.004 & 0.004 & 0.000 & & & & & & & & & & & & & & & & & & \\
\hline 10 & AB128057.1. Lingula adamsi (South Korea) & 0.400 & 0.400 & 0.400 & 0.396 & 0.396 & 0.006 & 0.006 & 0.002 & 0.002 & & & & & & & & & & & & & & & & & \\
\hline 11 & AB128060.1. Lingula adamsi (South Korea) & 0.400 & 0.400 & 0.400 & 0.396 & 0.396 & 0.004 & 0.004 & 0.000 & 0.000 & 0.002 & & & & & & & & & & & & & & & & \\
\hline 12 & AB128061.1. Lingula adamsi (South Korea) & 0.400 & 0.400 & 0.400 & 0.396 & 0.395 & 0.006 & 0.006 & 0.002 & 0.002 & 0.004 & 0.002 & & & & & & & & & & & & & & & \\
\hline 13 & AB128056.1. Lingula adamsi (South Korea) & 0,408 & 0,408 & 0,408 & 0,396 & 0.396 & 0.017 & 0,017 & 0.013 & 0.013 & 0.015 & 0.013 & 0.015 & & & & & & & & & & & & & & \\
\hline 14 & AB128062.1. Lingula adamsi (South Korea) & 0.396 & 0.396 & 0.396 & 0.392 & 0.400 & 0.008 & 0.008 & 0.004 & 0.004 & 0.006 & 0.004 & 0.006 & 0.017 & & & & & & & & & & & & & \\
\hline 15 & AB128063.1. Lingula adamsi (South Korea) & 0.687 & 0.687 & 0.687 & 0.665 & 0.676 & 0.718 & 0.718 & 0.712 & 0.712 & 0.712 & 0.712 & 0.717 & 0.712 & 0.700 & & & & & & & & & & & & \\
\hline 16 & AB026506.1. Pictothyris picta (Japan) & 0.791 & 0.791 & 0.791 & 0.773 & 0.773 & 0.679 & 0.679 & 0.673 & 0.673 & 0.673 & 0,673 & 0.673 & 0.689 & 0.684 & 0.514 & & & & & & & & & & & \\
\hline 17 & AB026519.1. Novocrania japonicus (Japan) & 0.312 & 0.312 & 0.312 & 0.305 & 0.305 & 0.344 & 0.347 & 0.340 & 0.340 & 0.344 & 0,340 & 0.343 & 0.344 & 0.340 & 0.615 & 0.700 & & & & & & & & & & \\
\hline 18 & AB056461.1. Lingula anatina (Hongkong) & 0.289 & 0.289 & 0.289 & 0.296 & 0.296 & 0.351 & 0.355 & 0.348 & 0.348 & 0.348 & 0,348 & 0.348 & 0.362 & 0.344 & 0.675 & 0.773 & 0.335 & & & & & & & & & \\
\hline 19 & AB026520.1. Lingula anatina (Japan) & 0.286 & 0.286 & 0.286 & 0.293 & 0.293 & 0.352 & 0.355 & 0.348 & 0.348 & 0.348 & 0,348 & 0.348 & 0.363 & 0.345 & 0.676 & 0.767 & 0.332 & 0.002 & & & & & & & & \\
\hline 20 & AB056460.1. Lingula anatina (Japan) & 0.302 & 0.302 & 0.302 & 0.305 & 0.305 & 0.315 & 0.318 & 0.318 & 0.318 & 0.318 & 0,318 & 0.322 & 0.332 & 0.315 & 0.666 & 0.751 & 0.332 & 0.076 & 0.073 & & & & & & & \\
\hline 21 & GU056041.1. Lingula anatina (China) & 0.295 & 0.295 & 0.295 & 0.298 & 0.299 & 0.308 & 0.312 & 0.312 & 0.312 & 0.312 & 0.312 & 0.315 & 0.325 & 0.308 & 0.660 & 0.745 & 0.325 & 0.071 & 0.069 & 0.004 & & & & & & \\
\hline 22 & GU056040.1. Lingula anatina (China) & 0.302 & 0.302 & 0.302 & 0.312 & 0.312 & 0.336 & 0.339 & 0.339 & 0.339 & 0.339 & 0.339 & 0.342 & 0.353 & 0.336 & 0.683 & 0.751 & 0.357 & 0.097 & 0.095 & 0.028 & 0.028 & & & & & \\
\hline 23 & KY091122.1. Lingula anatina (South Korea) & 0.315 & 0.315 & 0.315 & 0.318 & 0.319 & 0.329 & 0.332 & 0.332 & 0.332 & 0.332 & 0.332 & 0.335 & 0.346 & 0.329 & 0.671 & 0.739 & 0.349 & 0.113 & 0.113 & 0.044 & 0.044 & 0.015 & & & & \\
\hline 24 & KY091123.1. Lingula anatina (South Korea) & 0.315 & 0.315 & 0.315 & 0.311 & 0.311 & 0.328 & 0.332 & 0.332 & 0.332 & 0.332 & 0.332 & 0.335 & 0.346 & 0.328 & 0.664 & 0.727 & 0.337 & 0,110 & 0.110 & 0.048 & 0.043 & 0.037 & 0.021 & & & \\
\hline 25 & KY091124.1. Lingula anatina (South Korea) & 0.324 & 0.324 & 0.324 & 0.321 & 0.321 & 0.342 & 0.338 & 0.345 & 0.345 & 0.345 & 0.345 & 0.348 & 0.360 & 0.342 & 0.686 & 0.744 & 0.359 & 0.120 & 0.120 & 0.053 & 0.053 & 0.028 & 0.013 & 0.013 & & \\
\hline 26 & KY091125.1. Lingula anatina (South Korea) & 0.315 & 0.315 & 0.315 & 0.311 & 0.311 & 0.328 & 0.332 & 0.332 & 0.332 & 0.332 & 0.332 & 0.335 & 0.346 & 0.328 & 0.664 & 0.727 & 0.337 & 0.110 & 0.110 & 0.048 & 0.043 & 0.037 & 0.021 & 0.013 & 0.013 & \\
\hline
\end{tabular}



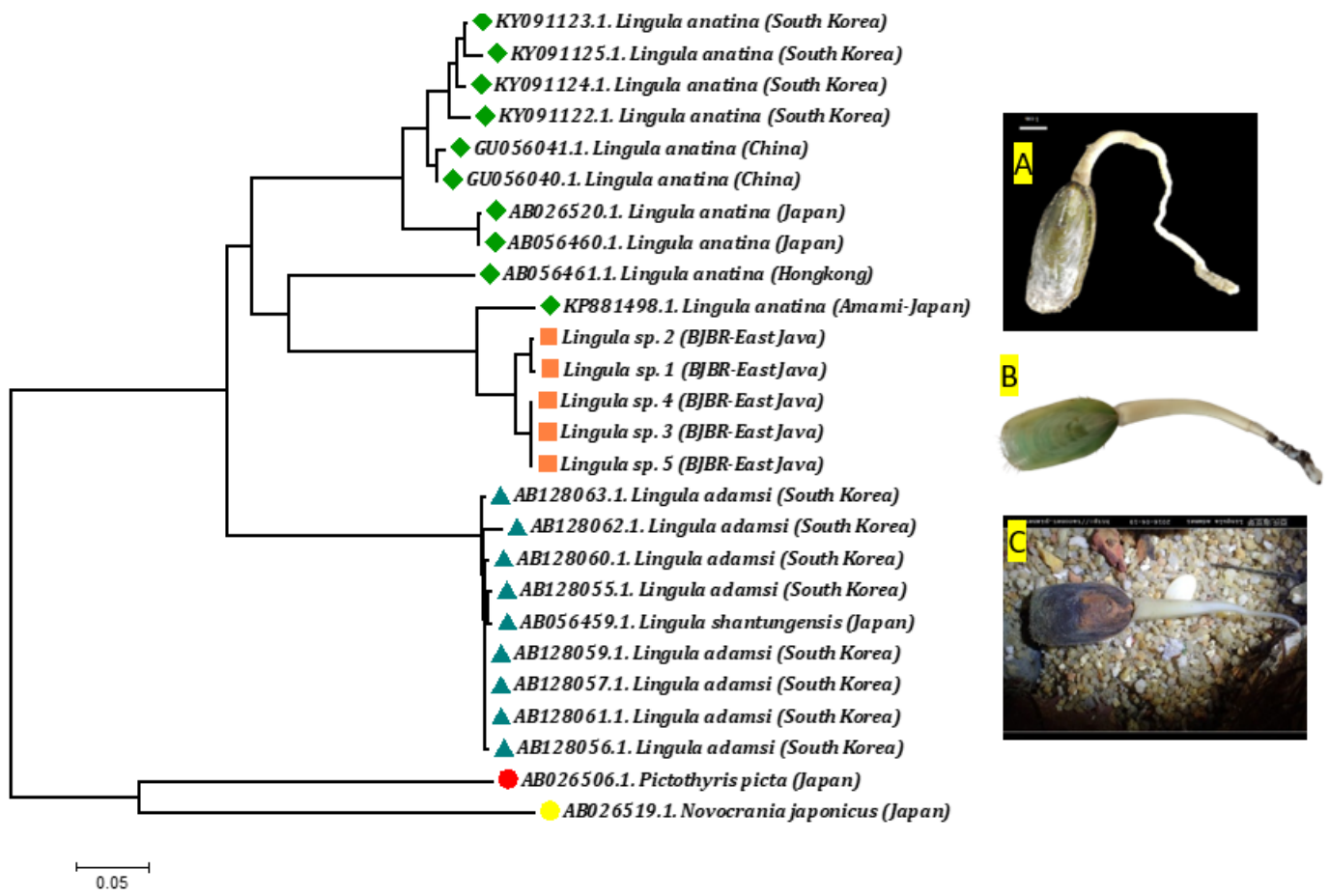

Figure 3. Phylogenetic topology using the Neighbor Joining Method with the Kimura 2 model parameter calculation model using 1000x bootstrap. Note: A. Lingula anatina (Kim et al. 2017); B. Lingula sp. (this study); C. Lingula adamsi (Yang et al. 2013). The symbol in this tree shows the different species based on locality.
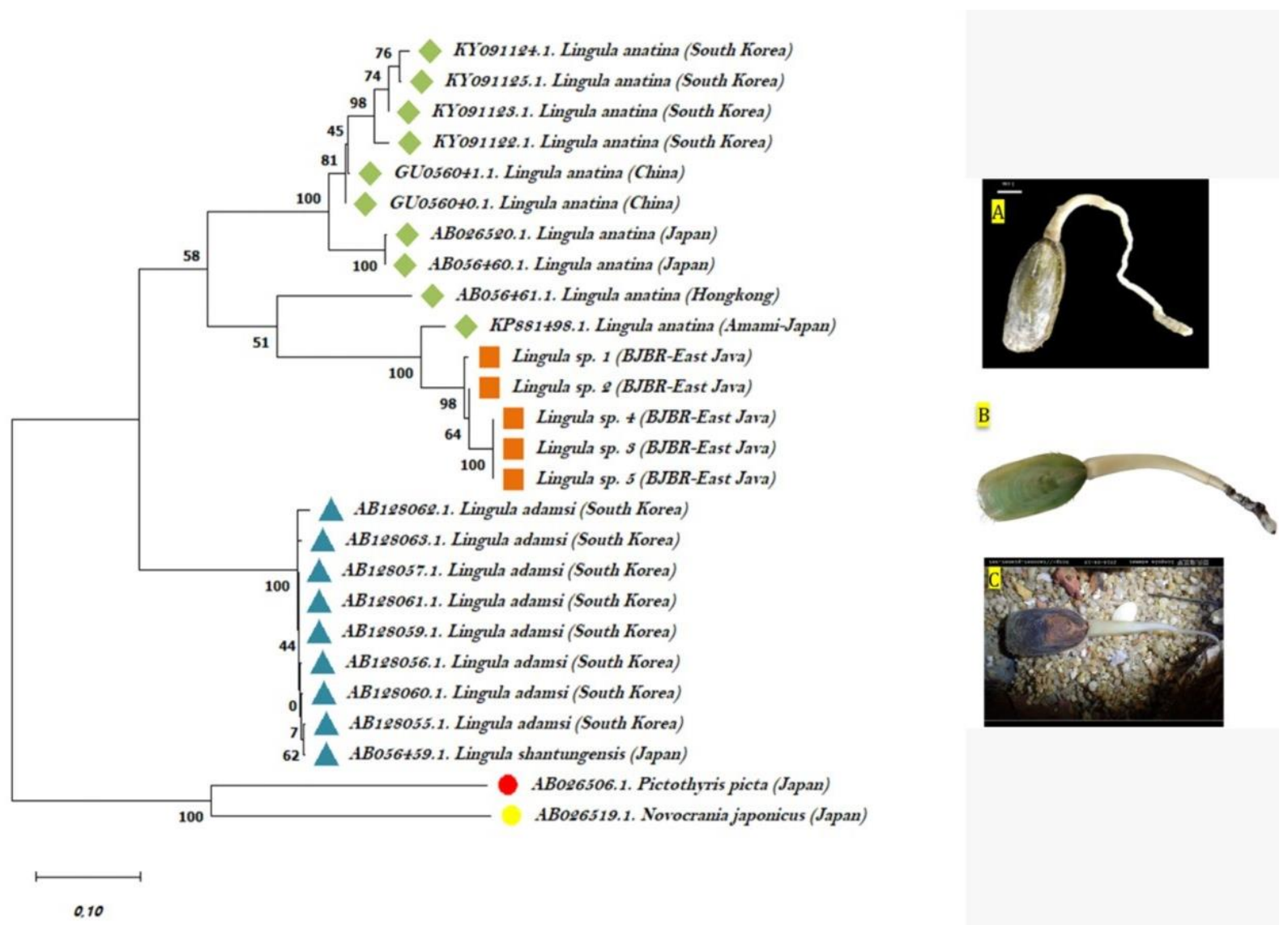

B
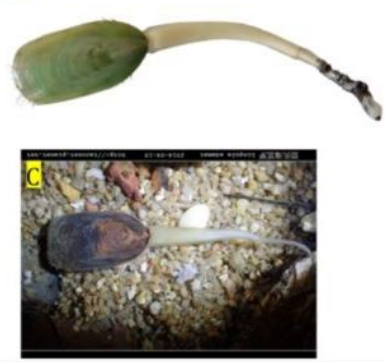

Figure 4. Phylogenetic topology using the Maximum Likelihood Method and the Kimura 2 Parameter Model calculation at 1000x bootstrap. Note: A. Lingula anatina (Kim et al. 2017); B. Lingula sp. (this study); C. Lingula adamsi (Yang et al. 2013). The symbol in this tree shows the different species based on locality. 


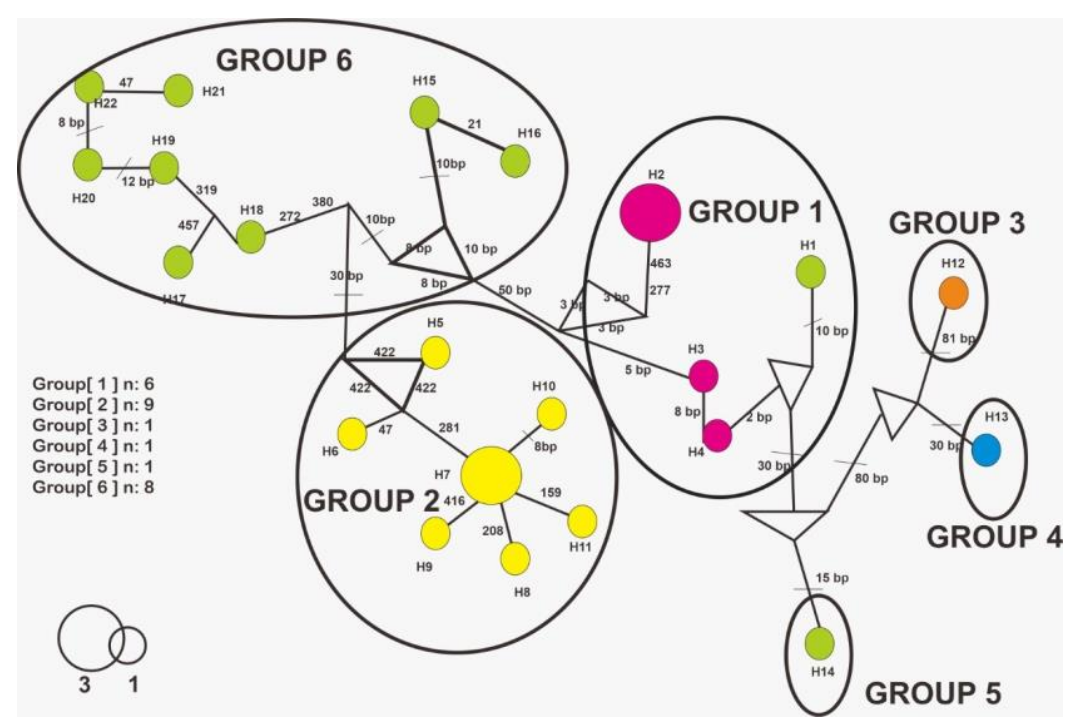

Figure 5. Haplotype network of Lingula sp., compared to close relatives. The haplotype network is based on 22 haplotypes from COI gene sequences, represented by different circular shapes and patterns, and branching is indicated by substitution, based on the position of the alignment of the COI gene sequences. The color shows the different haplotype and locality, while each circle represents a single haplotype, with size proportional to frequency

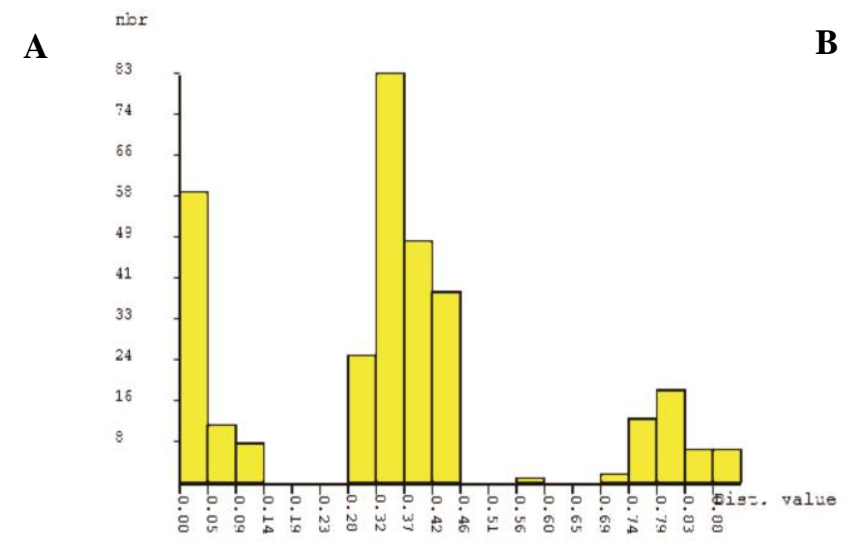

C

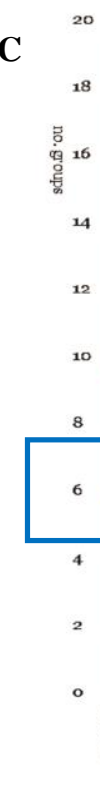

B Dig:. value

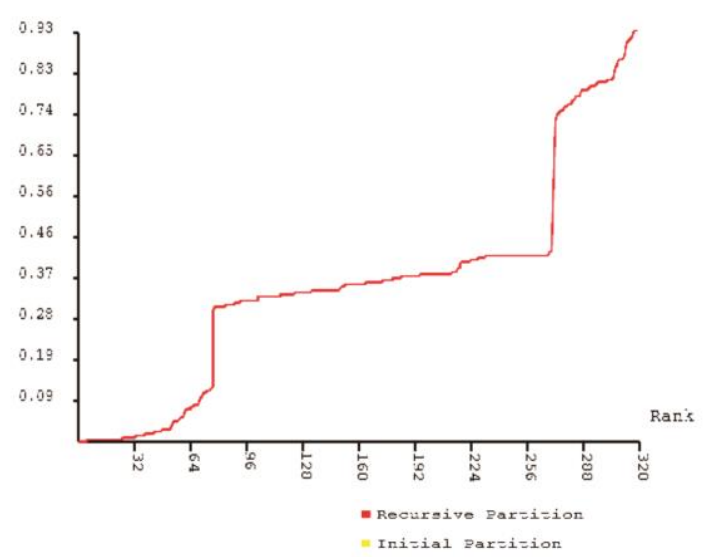

Figure 6. Barcode gap analysis of Lingula sp. species generated by Automatic Barcode Gap Discovery, and distributions of Kimura 2 Parameter (K2P) distances between each pair of COI gene specimens (A) histogram of distance (B) ranked distance and (C) number of Primary Species Hypotheses (PSHs) obtained, for each prior intraspecific divergence 
Thus, there were several genetic characterizations and molecular taxonomy of Lingula anatina from Probolinggo, East Java identified in this study, with the capacity to become primary information and support for further studies. Furthermore, conservation management of Lingula anatina is possible in grouping animal units according to species and genetic entity, as well as the potential of developing cryopreservation for sustainability.

Based on the results, the lamp shells from Probolinggo, Indonesia, were concluded to be Lingula anatina. Haplotype Lingula anatina from Probolinggo, East Java was different, because the five individuals were not homologous to reference species, despite being in the same haplogroup as Lingula anatina from Amami, Japan and haplotype as well as ABGD analysis group, with Lingula anatina (Amami Japan).

\section{ACKNOWLEDGEMENTS}

We wish to thank Dr. Umie Lestari, from molecular laboratory for the assistance during laboratory work. We are also grateful to Dr. Dwi Sendi Priyono, for the valuable input to improve the manuscript.

\section{REFERENCES}

Alberti M, Fürsich FT, Abdelhady AA, Andersen N. 2017. Middle to Late Jurassic equatorial seawater temperatures and latitudinal temperature gradients based on stable isotopes of brachiopods and oysters from Gebel Maghara, Egypt. Palaeogeogr Palaeoclim Palaeoecol 468: 301313. DOI: 10.1016/j.palaeo.2016.11.052.

Ambarwati R, Rahayu DA, Faizah U. 2019. The potency and food safety of Lamp Shells (Brachiopoda: Lingula sp.) as Food Resources. J Phys Conf Ser 1417: 12039. DOI: 10.1088/1742-6596/1417/1/012039.

Anzani L, Madduppa HH, Nurjaya IW, Dias PJ. 2019. Short communication: Molecular identification of white sea squirt Didemnum sp. (Tunicata, Ascidiacea) colonies growing over corals in Raja Ampat Islands, Indonesia. Biodiversitas 20 (3): 636-642. DOI: 10.13057/biodiv/d200304.

Artimo P, Jonnalagedda M, Arnold K, Baratin D, Csardi G, De Castro E, Duvaud S, Flegel V, Fortier A, Gasteiger E, Grosdidier A, Hernandez C, Ioannidis V, Kuznetsov D, Liechti R, Moretti, S, Mostaguir K Redaschi N, Rossier G, et al. 2012. ExPASy: SIB bioinformatics resource portal. Nucleic Acids Res 40 (W1). DOI: 10.1093/nar/gks400.

Bensasson D, Zhang DX, Hartl DL, Hewitt GM. 2001. Mitochondrial pseudogenes: Evolution's misplaced witnesses. Trends Ecol Evol 16 (6): 314-321. DOI: 10.1016/S0169-5347 (01)02151-6.

Bitner MA, Romanin M. 2018. Recent brachiopods collected during the ZhongSha 2015 expedition to the South China Sea, West Pacific. Mar Biol Res 14 (6): 551-564. DOI: 10.1080/17451000.2018.1502447.

Buhay JE. 2009. "COI-like" sequences are becoming problematic in molecular systematic and DNA barcoding studies. J Crustacean Biol 29 (1): 96-110. DOI: 10.1651/08-3020.1.

Chenna R, Sugawara H, Koike T, Lopez R, Gibson TJ, Higgins DG, Thompson JD. 2003. Multiple sequence alignment with the Clusta series of programs. Nucleic Acids Res 31 (13): 3497-3500. DOI: 10.1093/nar/gkg500.

Darmarini AS, Wardiatno Y, Prartono T, Soewardi K. 2017. Shor communication: New record of primitive brachiopod, Lingula sp. in mangrove ecosystem of Lubuk Damar, Aceh Tamiang, Indonesia. Biodiversitas 18 (4): 1438-1444. DOI: 10.13057/biodiv/d180420.

Endo K, Noguchi Y, Ueshima R, Jacobs HT. 2005. Novel repetitive structures, deviant protein-encoding sequences and unidentified ORFs in the mitochondrial genome of the brachiopod Lingula anatina. J Mol Evol 61 (1): 36-53. DOI: 10.1007/s00239-004-0214-5.

Esa YB, Siraj SS, Daud SK, Rahim KAA, Japning JRR, Tan SG. 2008. Mitochondrial DNA diversity of Tor tambroides Valenciennes (Cyprinidae) from five natural populations in Malaysia. Zool Stud 47 (3): 360-367.

Emig CC, Bitner MA, Alvarez F. 2013. Phylum Brachiopoda. Zootaxa 3703: 75-78. DOI: 10.11646/zootaxa.3703.1.15.

Feldman HR. 2017. Tunethyris blodgetti sp. nov. (Brachiopoda, Terebratulida) from the Middle Triassic of Makhtesh Ramon, southern Israel. Annales Societatis Geologorum Poloniae 87 (1): 8999. DOI: 10.14241/asgp.2017.004.

Goto R, Ishikawa H, Hamamura Y, Sato S, Kato M. 2014. Evolution of symbiosis with Lingula (Brachiopoda) in the bivalve Superfamily Galeommatoidea (Heterodonta), with description of a new species of Koreamya. J Molluscan Stud 80: 148-160. DOI: 10.1093/mollus/eyu009.

Folmer O, Black M, Hoe, W, Lutz R, Vrijenhoek R. 1994. DNA primers for amplification of mitochondrial cytochrome $\mathrm{c}$ oxidase subunit I from diverse metazoan invertebrates. Mol Mar Biol Biotechnol 3 (5): 294-299. DOI: 10.1071/ZO9660275.

Hajibabaei M, Singer GAC, Hebert PDN, Hickey DA. 2007. DNA barcoding: how it complements taxonomy, molecular phylogenetics and population genetics. Trends Genet 23 (4): 167-172. DOI: 10.1016/j.tig.2007.02.001

Hebert PDN, Cywinska A, Ball SL, DeWaard JR. 2003. Biological identifications through DNA barcodes. Proc R Soc B Biol Sci270 (1512): 313-321. DOI: 10.1098/rspb.2002.2218.

Hebert PDN, Gregory TR. 2005. The promise of DNA barcoding for taxonomy. Syst Biol 54 (5): 852-859. DOI: 10.1080/10635150500354886

Hebert PDN, Stoeckle MY, Zemlak TS, Francis CM. 2004. Identification of birds through DNA barcodes. PLoS Biol 2 (10). DOI: 10.1371/journal.pbio.0020312.

Hesterberg T. 2015. Bootstrap Methods and Permutation tetes (Issue January).

Jackson J, Stiasny G. 1937. The Brachiopoda of the Siboga Expedition. "Siboga Expeditie" XXVII.

Jefri E, Zamani NP, Subhan B, Madduppa HH. 2015. Molecular phylogeny inferred from mitochondrial DNA of the grouper Epinephelus spp. In Indonesia collected from local fish market. Biodiversitas 16 (2): 254-263. DOI: 10.13057/biodiv/d160221.

Kenchington R, Hammond L. 1978. Population structure, growth and distribution of Lingula anatina (Brachiopoda) in Queensland, Australia. J Zool Lond 184: 63-81.

Kim SG, Karagozlu MZ, Kim CB. 2017. Phylogenetic investigations of Lingula anatina among some northwestern Pacific populations, based on mitochondrial DNA cytochrome c oxidase subunit I gene. J AsiaPac Biodiv 10 (2): 162-166. DOI: 10.1016/j.japb.2017.04.007.

Leopardas V, Honda K, Go GA, Bolisay K, Pantallano AD, Uy W, Fortes M, Nakaoka M. 2016. Variation in macrofaunal communities of seagrass beds along a pollution gradient in Bolinao, northwestern Philippines. Mar Pol Bull 105 (1): 310-318. DOI: 10.1016/j.marpolbul.2016.02.004.

Luo YJ, Takeuchi T, Koyanagi R, Yamada L, Kanda M, Khalturina M, Fujie M, Yamasaki SI, Endo K, Satoh N. 2015. The Lingula genome provides insights into brachiopod evolution and the origin of phosphate biomineralization. Nature Commun 6. DOI: 10.1038/ncomms9301.

Madduppa H, Taurusman AA, Subhan B, Anggraini NP, Fadillah R, Tarman K. 2017. Short communication: DNA barcoding reveals vulnerable and not evaluated species of sea cucumbers (Holothuroidea and Stichopodidae) from Kepulauan Seribu reefs, $\begin{array}{llll}\text { Indonesia. Biodiversitas } 18 & \text { (3): 893-898. DOI: }\end{array}$ 10.13057/biodiv/d180305.

Martins S, Simões F, Mendonça D, Matos J, Silva AP, Carnide V. 2013. Median-joining networks for inferring intraspecific phylogenies. Genet Res Crop Evol 60 (4): 37-48. DOI: 10.1007/978-94-009-120762.

Mikkelsen NT, Schander C, Willassen E. 2007. Local-scale DNA barcoding of bivalves (Mollusca): A case study. Zoologica Scripta 36 (5): 455-463. DOI: 10.1111/j.1463-6409.2006.00289.x. 
Mitra S, Pattanayak JG. 2013. Studies on Lingula anatina (Brachiopoda: Inarticulata) in Subarnarekha Estuary, Odisha with special reference to habitat and population. Rec Zool Surv India 113 (Part 3): 49-53.

Nayak A, Charan KB, Lovaraju A, Raut D, Sanghamitra RS, Dash B, Patnaik L, Mohanty B, Raman A. 2018. Benthic infauna from mudflats of Atharbanki mangrove waterway in Odisha, India. J Mar Biol Assoc India 60 (1): 33-39. DOI: 10.6024/jmbai.2018.60.1.202605.

Nugroho ED, Nawir D, Amin M, Lestari U. 2017. DNA barcoding of nomei fish (Synodontidae: Harpadon sp.) in Tarakan Island, Indonesia. AACL Bioflux 10 (6): 1466-1474.

Priyono DS, Solihin DD, Farajallah A, Arini DID. 2018. Anoa, dwarf buffalo from Sulawesi, Indonesia: Identification based on DNA barcode. Biodiversitas 19 (6): 1985-1992. DOI 10.13057/biodiv/d190602.

Puillandre N, Lambert A, Brouillet S, Achaz G. 2012. ABGD, Automatic Barcode Gap Discovery for primary species delimitation. Mol Ecol 21 (8): 1864-1877. DOI: 10.1111/j.1365-294X.2011.05239.x.

Rakmawati R, Ambarwati, R. 2019. Komunitas bivalvia yang berasosiasi dengan Kerang Lentera (Brachiopoda: Lingulata) di zona intertidal Selat Madura. Jurnal Riset Biologi dan Aplikasinya 2 (1): 36-42. [Indonesian]

Rozas J, Rozas R. 1995. DnaSP, DNA sequence polymorphism: An interactive program for estimating population genetics parameters from DNA sequence data. Comp Appl Biosci 11 (6): 621-625. DOI: 10.1093/bioinformatics/11.6.621.

Sahidin A, Zahidah Z, Herawati H, Wardiatno Y, Setyobudiandi I, Partasasmita R. 2018. Macrozoobenthos as bioindicator of ecological status in Tanjung Pasir Coastal, Tangerang District, Banten Province, Indonesia. Biodiversitas 19 (3): 1123-1129. DOI 10.13057/biodiv/d190347.

Samanta S, Choudhury A, Chakraborty SK. 2014. Morpho-anatomical study of Lingula anatina Lamarck, 1801 from West Bengal-Odisha coast, India. J Mar Biol Assoc India 56 (2): 26-33. DOI: 10.6024/jmbai.2014.56.2.01775-04.

Samanta S, Choudhury A, Chakraborty SK. 2015. Eco-biology of a Precambrian intertidal benthic brachiopod, Lingula anatina from the confluence of Subarnarekha estuary with Bay of Bengal, India. J Mar Biol Assoc India 57 (1): 41-46. DOI: 10.6024/jmbai.2015.57.1.183606

Susanto AH, Nuryanto A, Soedibja PHT. 2012. Phylogeography and genetic diversity of humpback grouper Cromileptes altivelis based on Cytochrome C Oxidase I. Jurnal Natur Indonesia 14 (1): 47-51. DOI: 10.31258/jnat.14.1.47-51.

Tamura K, Stecher G, Peterson D, Filipski A, Kumar, S. 2013. MEGA6: Molecular evolutionary genetics analysis version 6.0. Mol Biol Evol 30 (12): 2725-2729. DOI: 10.1093/molbev/mst197.

Wallace DC, Chalkia D. 2013. Mitochondrial DNA genetics and the heteroplasmy conundrum in evolution and disease. Cold Spring Harbor Perspect Med 3 (10): 1-47.

Waugh J, Huynen L, Millar C, Lambert, D. 2008. DNA barcoding of animal species - Response to DeSalle [1]. BioEssays 30 (1): 92-93. DOI: $10.1002 /$ bies.20698.

Wibowo A, Farajalah A, Husnah H. 2013. DNA barcoding of freshwater fish species of Manna river (Bengkulu) and Semanka river (Lampung). Indon Fish Res J 19 (1): $9 . \quad$ DOI: 10.15578/ifrj.19.1.2013.9-17.

Wong EHK, Shivji MS, Hanner RH. 2009. Identifying sharks with DNA barcodes: Assessing the utility of a nucleotide diagnostic approach. Mol Ecol Resour 9 (suppl. 1): 243-256. DOI: 10.1111/j.17550998.2009.02653.x.

Yang S, Lai X, Sheng G, Wang S. 2013. Deep genetic divergence within a "living fossil" brachiopod Lingula anatina. J Paleontol 87 (5): 902908. DOI: 10.1666/12-127. 